\title{
Bacillus vietnamensis sp. nov., a moderately halotolerant, aerobic, endospore-forming bacterium isolated from Vietnamese fish sauce
}

\author{
Haruko Noguchi, ${ }^{1}$ Masataka Uchino, ${ }^{1}$ Osamu Shida, ${ }^{2}$ Katsumi Takano, ${ }^{1}$ \\ Lawrence K. Nakamura ${ }^{3}$ and Kazuo Komagata ${ }^{1}$
}

Correspondence

Masataka Uchino muchino@nodai.ac.jp

\begin{abstract}
'Department of Applied Biology and Chemistry, Faculty of Applied Bioscience, Tokyo University of Agriculture, Sakuragaoka 1-1-1, Setagaya-ku, Tokyo 156-8502, Japan
\end{abstract}

${ }^{2} R$ \& D Department, Higeta Shoyu Co., Ltd, Choshi, Chiba 288-8680, Japan

${ }^{3}$ Microbial Properties Research, National Center for Agricultural Utilization Research, US Department of Agriculture, Peoria, IL 61604, USA

Five strains of Gram-positive, endospore-forming, moderately halotolerant bacteria were studied taxonomically. Four were isolated from Vietnamese fish sauce and one from the Gulf of Mexico. Phylogenetic analysis based on 16S rRNA gene sequences showed that these strains clustered within the radiation of the genus Bacillus but separately from recognized Bacillus species. DNA G $+C$ composition of the isolates ranged from 43 to 44 mol\%. Strains $15-1^{\top}$ and NRRL B-14850 showed high levels of DNA-DNA relatedness (82-100\%) to each other and to the other strains isolated here; they displayed low levels of DNA-DNA relatedness $(<29 \%)$ to the type strains of selected recognized Bacillus species. They grew in $15 \% \mathrm{NaCl}$ and optimally in $1 \% \mathrm{NaCl}$, which is characteristic of moderately halotolerant bacteria. The isolates grew at $\mathrm{pH} 6.5$ to 10.0 but not at $\mathrm{pH} 6.0$. Their cell walls contained meso-diaminopimelic acid. The major isoprenoid quinone was MK-7 and the principal cellular fatty acids were anteiso- $C_{15: 0}$, iso- $C_{15: 0}$ and anteiso- $C_{17: 0}$. Based on these results, the strains tested were regarded as members of a novel Bacillus species for which the name Bacillus vietnamensis sp. nov. is proposed. The type strain is $15-1^{\top}\left(=\mathrm{JCM} 11124^{\top}=\mathrm{NRIC} 0531^{\top}=\mathrm{NRRL} 23890^{\top}\right)$.
The ubiquity of Bacillus species and closely related bacteria in fermented fish products implied their importance in the preparation of these food materials. The results of several studies have supported this conjecture. For example, Itoh et al. (1993) verified the participation of bacteria in fish sauce fermentations. Bacillus strains have been isolated from fermented fish in Vietnam and Japan (Crisan \& Sands, 1975). Researchers have isolated proteolytic Halobacillus (Choorit \& Prasertsan, 1992) and Bacillus from fermented fish in Thailand (Chaiyanan et al., 1999). Isolates of Bacillus species and moderately halophilic bacteria were recovered from Korean fermented seafoods (Sands \& Crisan, 1974; Yoon et al., 2001). Bacillus species have been isolated from nam-pla, a Thai fermented fish sauce (Saisithi et al., 1966; Crisan \& Sands, 1975). Mura et al. (2000) isolated four Bacillus strains from nuoc mam, a Vietnamese fish sauce; these isolates resembled Bacillus firmus phenotypically but

Published online ahead of print on 14 May 2004 as DOI 10.1099/ ijs.0.02895-0.

The GenBank/EMBL/DDBJ accession number for the 16S rRNA gene sequence of Bacillus vietnamensis strain $15-1^{\top}$ is AB099708. showed a low level of DNA-DNA relatedness with the type strain of the species. Because these bacteria apparently originated mainly from marine fish, raw materials for production of fish sauce in Vietnam, the isolates were presumed to be halophilic or halotolerant. Yoon et al. (2003) have described two Bacillus species, Bacillus marisflavi and Bacillus aquimaris, isolated from sea water.

Preliminary comparisons of $16 \mathrm{~S}$ rRNA gene sequences suggested a close relationship between the four abovementioned Bacillus strains from nuoc mam and NRRL B-14850, an unidentified Bacillus isolate from the Gulf of Mexico (Siefert et al., 2000). These five strains were studied to clarify their taxonomic position by $16 \mathrm{~S}$ rRNA gene sequences, levels of DNA-DNA relatedness, DNA base compositions, chemotaxonomic properties and phenotypic characteristics. The data indicated that the five strains were members of a novel species, for which we propose the name Bacillus vietnamensis sp. nov.

Four strains $\left(11-4,15-1^{\mathrm{T}}, 16-3\right.$ and 20-1) isolated by Mura et al. (2000) and strain NRRL B-14850 were used in this study. Reference strains used were Bacillus amyloliquefaciens 
DSM $7^{\mathrm{T}}$, Bacillus aquimaris TF-12 ${ }^{\mathrm{T}}$, Bacillus atrophaeus IFO $15539^{\mathrm{T}}$, Bacillus firmus JCM $2512^{\mathrm{T}}$, Bacillus lentus JCM $2511^{\mathrm{T}}$, Bacillus licheniformis JCM $2505^{\mathrm{T}}$, Bacillus marisflavi $\mathrm{TF}-11^{\mathrm{T}}$, Bacillus mojavensis NRRL B-14698 ${ }^{\mathrm{T}}$, Bacillus pumilus JCM $2508^{\mathrm{T}}$, Bacillus subtilis JCM $1465^{\mathrm{T}}$ and Bacillus vallismortis NRRL B-14890 ${ }^{\mathrm{T}}$. Trypticase soy agar (Difco) was used as a basal medium and as a stock culture medium. Strains were stored at $4{ }^{\circ} \mathrm{C}$.

Determination of the taxonomic relationships of the five isolates was based on $16 \mathrm{~S}$ rRNA gene sequences. Sequencing was carried out using the methods reported by Shida et al. (1996) and Takagi et al. (1993). Sequences determined in this study were compared with 16S rRNA gene sequences obtained from EMBL/GenBank/DDBJ. Multiple alignment of sequences, calculation of nucleotide substitution rates ( $K_{\text {nuc }}$ value) (Kimura, 1980), construction of a neighbour-joining phylogenetic tree (Saitou \& Nei, 1987) and a bootstrap analysis with 1000 replicates for evaluation of phylogenetic tree topology (Felsenstein, 1985) were carried out with CLUSTAL W version 1.6 (Thompson et al., 1994). Alignment gaps and unidentified base positions were not taken into account for the calculations. The 16S rRNA gene sequence of strain $15-1^{\mathrm{T}}(1200 \mathrm{bp})$ was determined. In addition, partial $16 \mathrm{~S}$ rRNA gene sequences (300-base segments corresponding to positions 200-500) were determined for the three other Bacillus strains (11-4, 16-3, 20-1) isolated from nuoc mam. 16S rRNA gene sequence data of NRRL B-14850 (1544 bp) and other endospore-forming aerobic bacteria were obtained from DDBJ/EMBL/GenBank.

DNA was extracted and purified with the Qiagen Genomictip system. Levels of DNA-DNA relatedness were determined fluorometrically (Ezaki et al., 1989). Probes were prepared with DNA from strain $15-1^{\mathrm{T}}$ and NRRL B-14850. DNA base compositions were determined by HPLC (Tamaoka \& Komagata, 1984).

Cellular fatty acid compositions, isoprenoid quinone compositions and isomers of diaminopimelic acid in the cell walls were determined by the methods of Komagata \& Suzuki (1987).

Morphological, physiological and biochemical characteristics were determined by the methods described by Gordon et al. (1973) and Takagi et al. (1993). Growth in various salt concentrations was tested using trypticase soy broth (Difco) as the basal medium. Cells were cultivated in trypticase soy broth containing $1 \%(\mathrm{w} / \mathrm{v}) \mathrm{NaCl}$ with shaking. After cultivation for $24 \mathrm{~h}$ at $37^{\circ} \mathrm{C}, 50 \mu \mathrm{l}$ culture was added to $2.5 \mathrm{ml}$ broth containing various $\mathrm{NaCl}$ concentrations and the inoculated broth was incubated on a reciprocal shaker (180 r.p.m.) at $37^{\circ} \mathrm{C}$. Growth was monitored spectrophotometrically at $660 \mathrm{~nm}$. Other phenotypic characteristics were determined by using API $50 \mathrm{CH}$ and $20 \mathrm{NE}$ kits (bioMérieux) (Logan \& Berkeley, 1984).

$16 \mathrm{~S}$ rRNA gene sequence similarity between strains $15-1^{\mathrm{T}}$ and NRRL B-14850 was $98 \cdot 6 \%$. The 300 -base sequences of isolates 11-4, 16-3 and 20-1 were nearly identical to one another and to the corresponding segment of strain $15-1^{\mathrm{T}}$ (data not shown). 16S rRNA gene sequence similarity values between strains $15-1^{\mathrm{T}}$ and NRRL B-14850 and selected members of the genus Bacillus were less than $95 \cdot 8 \%$. In a phylogenetic tree based on $16 \mathrm{~S}$ rRNA gene sequences, strain $15-1^{\mathrm{T}}$ and NRRL B-14850 formed a cluster with B. aquimaris and B. marisflavi within the genus Bacillus (Fig. 1); this cluster was linked to the $B$. subtilis group. 16S rRNA gene sequence similarities between strain $15-1^{\mathrm{T}}$ and B. aquimaris TF- $15^{\mathrm{T}}$ and B. marisflavi TF- $11^{\mathrm{T}}$ were $99 \cdot 4$ and $98 \cdot 6 \%$, respectively.

DNA-DNA relatedness values between strain $15-1^{\mathrm{T}}$ and the four other isolates were $88-100 \%$; similarity values between NRRL B-14850 and the four isolates ranged from 82 to $100 \%$. Less than $29 \%$ DNA-DNA relatedness was measured between strain $15-1^{\mathrm{T}}$ or NRRL B-14850 and species belonging to the $B$. subtilis group, namely $B$. amyloliquefaciens DSM $7^{\mathrm{T}}$, B. atrophaeus IFO $15539^{\mathrm{T}}$, B. firmus JCM $2512^{\mathrm{T}}$, B. lentus JCM $2511^{\mathrm{T}}$, B. licheniformis JCM $2505^{\mathrm{T}}$, B. mojavensis NRRL B-14698 ${ }^{\mathrm{T}}$, B. pumilus JCM $2508^{\mathrm{T}}$, B. subtilis JCM $1465^{\mathrm{T}}$ and B. vallismortis NRRL B- $14890^{\mathrm{T}}$, and marine Bacillus species $B$. aquimaris $\mathrm{TF}-12^{\mathrm{T}}$ and B. marisflavi $\mathrm{TF}-11^{\mathrm{T}}$.

The isolates showed virtually the same cell morphology and phenotypic characteristics: cells were rod-shaped, measuring $0.5-1 \cdot 0$ by $2 \cdot 0-3 \cdot 0 \mu \mathrm{m}$, Gram-positive and aerobic. Ellipsoidal spores developed centrally in the cells and sporangia were not swollen. Cells were motile with peritrichous flagella. The strains tested produced catalase and oxidase.

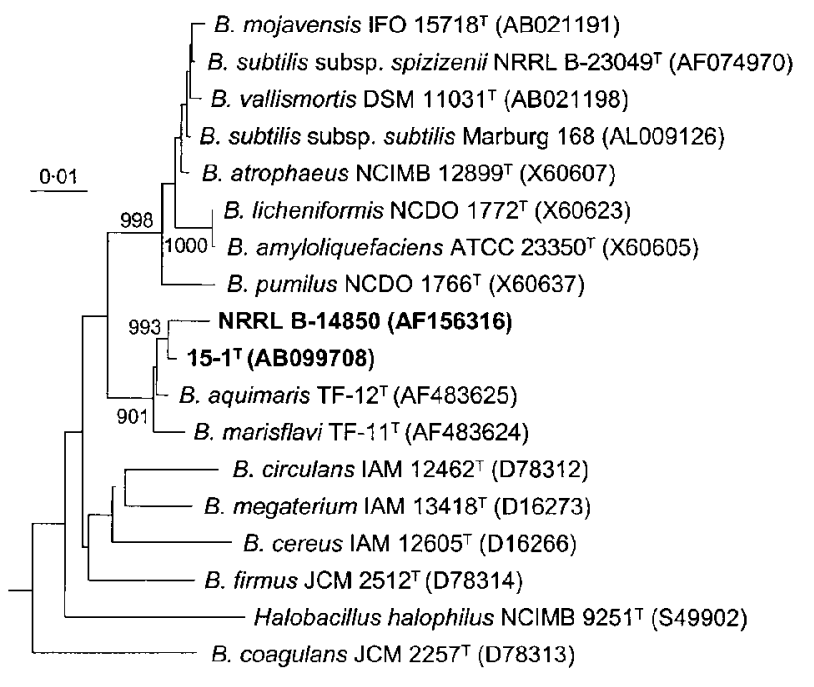

Fig. 1. Phylogenetic relationships of novel isolates and some aerobic endospore-forming bacteria on the basis of 16S rRNA gene sequence analysis. The branching pattern was generated by the neighbour-joining method. The numbers indicate bootstrap values from 1000 resamplings. Bar, 0.01 nucleotide substitution per sequence position. 
They grew in $15 \% \mathrm{NaCl}$, and optimally in $1 \% \mathrm{NaCl}$; they were therefore regarded as halotolerant bacteria. In addition, the isolates grew at $\mathrm{pH} 10 \cdot 0$ as alkaliphilic bacteria did but were phylogenetically distinct from these organisms (Fritze et al., 1990; Li et al., 2002). Other phenotypic characteristics are given in the species description below.

The isolates were differentiated from $B$. firmus based on the following characteristics: oxidase production, growth in $15 \% \mathrm{NaCl}$ and at $10{ }^{\circ} \mathrm{C}$, resistance to lysozyme, hydrolysis of gelatin, aesculin, $p$-nitrophenyl $\beta$-D-glucopyranoside and DNA and assimilation of gluconate. The isolates were positive for these traits, whereas $B$. firmus was negative. Differential characteristics with B. aquimaris and B. marisflavi were growth at $\mathrm{pH} 4 \cdot 5$ and $9 \cdot 0$, hydrolysis of aesculin and starch and acid production from $\mathrm{N}$-acetylglucosamine and inulin.

DNA $G+C$ content of the five isolates ranged from 43 to $44 \mathrm{~mol} \%$. The major cellular fatty acids of the five strains tested were anteiso- $\mathrm{C}_{15: 0}(48 \cdot 3 \pm 8 \cdot 6 \%)$, iso- $\mathrm{C}_{15: 0}$ $(16 \cdot 2 \pm 3 \cdot 7 \%)$, anteiso- $\mathrm{C}_{17: 0}(13 \cdot 6 \pm 4 \cdot 9 \%)$ and iso- $\mathrm{C}_{16: 0}$ $(11 \cdot 2 \pm 1 \cdot 8 \%)$. Fatty acids occurring in minor amounts were iso- $\mathrm{C}_{14: 0}(3 \cdot 7 \pm 1 \cdot 8 \%), \mathrm{C}_{14: 0}(1 \cdot 3 \pm 0 \cdot 8 \%), \mathrm{C}_{15: 0}$ $(1 \cdot 0 \pm 0 \cdot 5 \%), \quad \mathrm{C}_{16: 0} \quad(2 \cdot 8 \pm 0 \cdot 6 \%)$ and iso- $\mathrm{C}_{17: 0}$ $(1 \cdot 3 \pm 1 \cdot 0 \%)$. The isolates contained menaquinone 7 (MK-7), which accounted for more than $82 \%$ of the total menaquinones. meso-Diaminopimelic acid was found in the cell-wall peptidoglycan of the nuoc mam isolates. The above characteristics are traits frequently displayed by species of the genus Bacillus (Claus \& Berkeley, 1986).

Phylogenetic studies showed that the nuoc mam isolates (11-4, 15-1 $\left.{ }^{\mathrm{T}}, 16-3,20-1\right)$ and NRRL B-14850 were members of a distinct group within the genus Bacillus. Low levels of DNA-DNA relatedness between the isolates and members of the closest neighbouring clade, consisting of B. subtilislike organisms, supported the distinctiveness of the nuoc mam group. The nuoc mam isolates displayed characteristics typical of many Bacillus species, namely aerobic growth, spore production, major fatty acid composition of anteiso- $\mathrm{C}_{15: 0}$, iso- $\mathrm{C}_{15: 0}$, anteiso- $\mathrm{C}_{17: 0}$ and iso- $\mathrm{C}_{16: 0}$, predominance of the MK-7 menaquinone, occurrence of meso-diaminopimelic acid in the cell wall peptidoglycan and DNA G + C content of 43-44 $\mathrm{mol} \%$. The isolates were regarded as moderately halotolerant bacteria because they could grow in the presence of up to $15 \% \mathrm{NaCl}$ and optimally at $1 \%$ (Gilmour, 1990). This characteristic is generally regarded as typical of marine bacteria (Baumann \& Baumann, 1981).

Based on these results, we consider that the five strains merit recognition as a novel species of the genus Bacillus, for which we propose the name Bacillus vietnamensis sp. nov.

\section{Description of Bacillus vietnamensis sp. nov.}

Bacillus vietnamensis (vi.et.nam.en'sis. N.L. adj. vietnamensis referring to Vietnam, the country where the type strain was isolated).
Cells are rod-shaped, measuring $0 \cdot 5-1 \cdot 0$ by $2 \cdot 0-3 \cdot 0 \mu \mathrm{m}$, Gram-positive and aerobic. They are motile with peritrichous flagella. Ellipsoidal spores develop centrally in the cells and sporangia are not swollen. Catalase and oxidase are produced. Nitrate reduction, indole production, arginine dihydrolase and urease are negative. Growth occurs in the presence of lysozyme. Casein, starch, DNA, aesculin, gelatin, $p$-nitrophenyl $\beta$-D-galactopyranoside and tyrosine are hydrolysed. Production of hydrogen sulphide is not detected on trypticase soy agar. Acid is produced from glycerol, D-ribose, D-glucose, D-fructose, mannitol, $\mathrm{N}$-acetyl D-glucosamine, aesculin, maltose, sucrose, trehalose, inulin, starch and glycogen; no acid is produced from erythritol, D-arabinose, L-arabinose, D-xylose, L-xylose, adonitol, methyl $\alpha$-D-xyloside, galactose, D-mannose (NRRL B-14850 produces acid from this sugar), L-sorbose, rhamnose, dulcitol, inositol, sorbitol, methyl $\alpha$-D-mannoside, methyl $\beta$-Dglucoside, amygdalin, arbutin, salicin, cellobiose, lactose, melibiose, melezitose, D-raffinose, xylitol, $\beta$-gentiobiose, D-turanose, D-lyxose, D-tagatose, D-fucose, L-fucose, D-arabitol, L-arabitol, D-gluconate, 2-ketogluconate and 5-ketogluconate. Assimilation is positive for glucose, Dmannitol, $\mathrm{N}$-acetyl D-glucosamine, maltose, gluconate and DL-malic acid, and negative for L-arabinose, D-mannose, n-capric acid, citrate and adipic acid. Growth occurs at $0-15 \%(\mathrm{w} / \mathrm{v}) \mathrm{NaCl}$ (optimum at $1 \%)$. The isolates are regarded as moderately halotolerant bacteria. Growth occurs at $10-40{ }^{\circ} \mathrm{C}$ (optimum at $\left.30-40{ }^{\circ} \mathrm{C}\right)(16-3$ and NRRL B-14850 grow at $50^{\circ} \mathrm{C}$ ). Growth occurs at pH $6 \cdot 5-10 \cdot 0$ but not at pH 6.0. DNA G $+\mathrm{C}$ content is $43-44 \mathrm{~mol} \%$. The major fatty acid is anteiso- $\mathrm{C}_{15: 0}$ $(48 \cdot 3 \pm 11 \cdot 9 \%)$, with lesser iso- $C_{15: 0}(16 \cdot 2 \pm 4 \cdot 4 \%)$. The major quinone is MK-7. meso-Diaminopimelic acid is found in the cell walls. Strains have been isolated from Vietnamese fish sauce and from the Gulf of Mexico.

The type strain is strain $15-1^{\mathrm{T}}\left(=\mathrm{JCM} 11124^{\mathrm{T}}=\mathrm{NRIC}\right.$ $\left.0531^{\mathrm{T}}=\mathrm{NRRL} 23890^{\mathrm{T}}\right)$. The description of the type strain is the same as that of the species. DNA $\mathrm{G}+\mathrm{C}$ content is $43 \mathrm{~mol} \%$. Major cellular fatty acids are anteiso- $\mathrm{C}_{15: 0}$ $(51 \cdot 4 \%)$ and iso-C $15: 0(19 \cdot 8 \%)$. Isolation source is Vietnamese fish sauce.

\section{References}

Baumann, P. \& Baumann, L. (1981). The marine gram-negative eubacteria: genera Photobacterium, Beneckea, Alteromonas, Pseudomonas, and Alcaligenes. In The Prokaryotes, vol. 1, pp. 1302-1331. Edited by M. P. Starr, H. Stolp, H. G. Trüper, A. Balows \& H. G. Schlegel. New York: Springer.

Chaiyanan, S., Chaiyanan, S., Maugel, T., Hug, A., Robb, F. T. \& Colwell, R. R. (1999). Polyphasic taxonomy of a novel Halobacillus, Halobacillus thailandensis sp. nov. isolated from fish sauce. Syst Appl Microbiol 22, 360-365.

Choorit, W. \& Prasertsan, P. (1992). Characterization of protease produced by newly isolated and identified proteolytic microorganisms from fermented fish (Budu). World J Microbiol Biotechnol 8, 284-286. 
Claus, D. \& Berkeley, R. C. W. (1986). Genus Bacillus Cohn 1872, $174^{\mathrm{AL}}$. In Bergey's Manual of Systematic Bacteriology, vol. 2, pp. 1105-1139. Edited by P. H. A. Sneath, N. S. Mair, M. E. Sharpe \& J. B. Holt. Baltimore: Williams \& Wilkins.

Crisan, E. V. \& Sands, A. (1975). Microflora of four fermented fish sauces. Appl Microbiol 29, 106-108.

Ezaki, T., Hashimoto, Y. \& Yabuuchi, E. (1989). Fluorometric deoxyribonucleic acid-deoxyribonucleic acid hybridization in microdilution wells as an alternative to membrane filter hybridization in which radioisotopes are used to determine genetic relatedness among bacterial strains. Int J Syst Bacteriol 39, 224-229.

Felsenstein, J. (1985). Confidence limits on phylogenies; an approach using the bootstrap. Evolution 39, 783-791.

Fritze, D., Flobdorf, J. \& Claus, D. (1990). Taxonomy of alkaliphilic Bacillus strains. Int J Syst Bacteriol 40, 92-97.

Gilmour, D. (1990). Halotolerant and halophilic microorganisms. In Microbiology of Extreme Environments, pp. 147-177. Edited by C. A. Edwards. Milton Keynes, UK: Open University Press.

Gordon, R. E., Haynes, W. C. \& Pang, C. H.-N. (1973). The Genus Bacillus. Agriculture Handbook no. 427. Washington, DC: US Department of Agriculture.

Itoh, H., Tachi, H. \& Kikuchi, S. (1993). Fish fermentation technology in Japan. In Fish Fermentation Technology, pp. 177-186. Edited by C. H. Lee, K. H. Steinkraus \& P. J. A. Reilly. New York: United Nations University Press.

Kimura, M. (1980). A simple method for estimating evolutionary rates of base substitutions through comparative studies of nucleotide sequences. J Mol Evol 16, 111-120.

Komagata, K. \& Suzuki, K. (1987). Lipid and cell-wall analysis in bacterial systematics. Methods Microbiol 19, 161-207.

Li, Z., Kawamura, Y., Shida, O., Yamagata, S., Deguchi, T. \& Ezaki, T. (2002). Bacillus okuhidensis sp. nov., isolated from the Okuhida spa area of Japan. Int J Syst Evol Microbiol 52, 1205-1209.

Logan, N. A. \& Berkeley, R. C. W. (1984). Identification of Bacillus strains using the API system. J Gen Microbiol 130, 1871-1882.
Mura, K., Maeda, H., Tanaka, H., Koizumi, Y. \& Yanagida, F. (2000) Isolation of protease-productive bacteria from fish sauces collected in Vietnam. Food Preserv Sci 26, 263-271 (in Japanese).

Saisithi, P., Kasemsarn, B. O., Liston, J. \& Dollar, A. M. (1966). Microbiology and chemistry of fermented fish. J Food Sci 31, 105-110.

Saitou, N. \& Nei, M. (1987). The neighbor-joining method: a new method for reconstructing phylogenetic trees. Mol Biol Evol 4, 406-425.

Sands, A. \& Crisan, E. V. (1974). Microflora of fermented Korean seafoods. J Food Sci 39, 1002-1005.

Shida, O., Takagi, H., Kadowaki, K. \& Komagata, K. (1996). Proposal for two new genera, Brevibacillus gen. nov. and Aneurinibacillus gen. nov. Int J Syst Bacteriol 46, 939-946.

Siefert, J. L., Larios-Sanz, M., Nakamura, L. K., Slepecky, R. A., Paul, J. A., Moore, E. R., Fox, G. E. \& Jurtshuk, P., Jr (2000). Phylogeny of marine Bacillus isolates from the Gulf of Mexico. Curr Microbiol 41, 84-88.

Takagi, H., Shida, O., Kadowaki, K., Komagata, K. \& Udaka, S. (1993). Characterization of Bacillus brevis with descriptions of Bacillus migulanus sp. nov., Bacillus choshinensis sp. nov., Bacillus parabrevis sp. nov., and Bacillus galactophilus sp. nov. Int J Syst Bacteriol 43, 221-231.

Tamaoka, J. \& Komagata, K. (1984). Determination of DNA base composition by reversed-phase high performance liquid chromatography. FEMS Microbiol Lett 25, 125-128.

Thompson, J. D., Higgins, D. G. \& Gibson, T. J. (1994). CLUSTAL W: improving the sensitivity of progressive multiple sequence alignment through sequence weighting, position-specific gap penalties and weight matrix choice. Nucleic Acids Res 22, 4673-4680.

Yoon, J.-H., Kang, S.-S., Lee, K.-C., Kho, Y. H., Choi, S. H., Kang, K. H. \& Park, Y.-H. (2001). Bacillus jeotgali sp. nov., isolated from jeotgal, Korean traditional fermented seafood. Int J Syst Evol Microbiol 51, 1087-1092.

Yoon, J.-H., Kim, I.-G., Kang, K. H., Oh, T.-K. \& Park, Y.-H. (2003). Bacillus marisflavi sp. nov. and Bacillus aquimaris sp. nov., isolated from sea water of a tidal flat of the Yellow Sea in Korea. Int J Syst Evol Microbiol 53, 1297-1303. 